\title{
NUMERYCZNA ANALIZA PRZECIEKÓW OSIOWYCH W BEZOLEJOWEJ SPRĘŻARCE SPIRALNEJ W STANIE NIEUSTALONYM
}

\begin{abstract}
W pracy zaprezentowano wyniki rozważań na temat przecieków osiowych oraz ich wpływu na przebieg procesu sprężania w bezolejowej maszynie spiralnej. Za pomocą metody objętości skończonej zaproponowano dwuwymiarowy model zjawisk cieplno-przepływowych, uwzględniający warunki brzegowe w zmiennych polach prędkości, ciśnień i temperatur w komorach. Przedstawiono założenia obliczeń, wyniki, a także wnioski na temat wpływu przecieków na parametry termodynamiczne maszyny.
\end{abstract}

Słowa kluczowe: przecieki, sprężarka spiralna, modelowanie, maszyny rotacyjne

\section{Wprowadzenie}

Sprężarki spiralne to gazowe, rotacyjne maszyny energetyczne, o obrotowym ruchu organu roboczego [1]. Koncepcja maszyny spiralnej powstała w 1905 r. za sprawą francuskiego inżyniera Leona Creux. Jednak ze względu na brak odpowiednich technik i maszyn wytwórczych pierwsze komercyjne konstrukcje pojawiły się na rynku dopiero w latach 70. ubiegłego wieku [2]. Maszyny tego typu są projektowane jako urządzenia o małej i średniej wydajności oraz małym i średnim stopniu sprężania. Ich umiejscowienie pośród innych konstrukcji pokazano na rys. 1 . Sprawia to, że świetnie nadają się do zastosowania w układach chłodniczych, klimatyzacyjnych (także w klimatyzatorach samochodowych), jak również w obiegach pomp ciepła. Dodatkowo, nowym polem zastosowań jest wykorzystywanie maszyn spiralnych jako rozprężarek w układach ORC $[3,4]$. Zasada działania sprężarki spiralnej (rys. 2.) polega na współpracy dwóch łopatek w kształcie spirali. Jedna z łopatek porusza się ruchem mimośrodowym, druga natomiast pozostaje nieruchoma. W ten sposób oba elementy łączą się ze sobą w punktach styku, zależnych od kąta obrotu wału.

\footnotetext{
${ }^{1}$ Autor do korespondencji/corresponding author: Józef Rak, Politechnika Wrocławska, Plac Grunwaldzki 9, 50-370 Wrocław, tel.: (71) 3203091, e-mail: jozef.rak@pwr.edu.pl

${ }^{2}$ Zbigniew Gnutek, Politechnika Wrocławska, e-mail: zbigniew.gnutek@pwr.edu.pl
} 


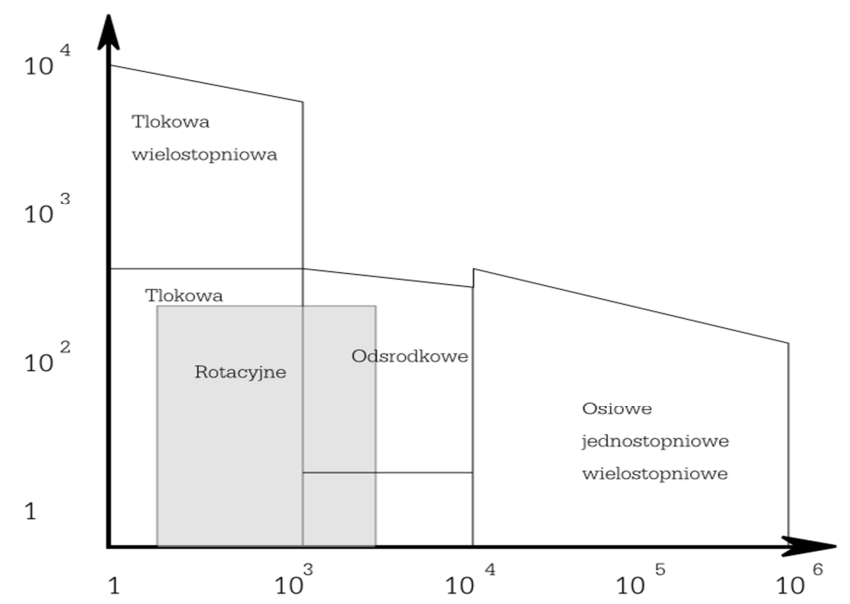

Rys. 1. Parametry osiagane przez maszyny rotacyjne

Fig. 1. Rotary machines parameters

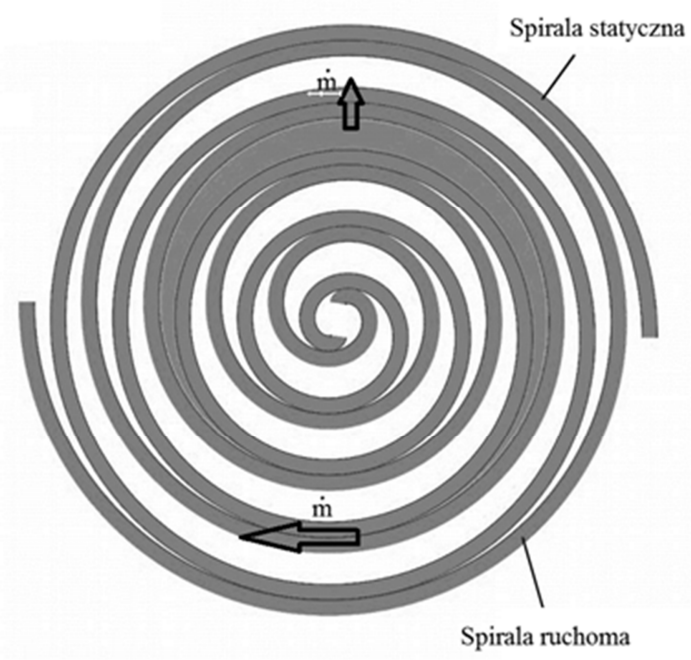

Rys. 2. Zasada działania sprężarki spiralnej oraz kierunek przecieków

Fig. 2. Principle of operation of scroll compressor and the leakage direction

Pomiędzy punktami wspólnymi tworzą się komory robocze, które w miarę trwania procesu zmniejszają swoją objętość i są przesuwane w kierunku części centralnej, gdzie znajduje się wylot. Komory robocze są oddzielone od siebie przez materiał łopatek, jednak nie są one zaizolowane idealnie. Ze względu na to, że jednocześnie jest uformowanych wiele komór o różnym stopniu zaawansowania procesu sprężania, czynnik roboczy jest tracony przez szczeliny od 
komór o wyższym ciśnieniu do sąsiadujących komór o niższym ciśnieniu. Rozróżnia się dwa rodzaje nieszczelności:

a) przeciek promieniowy - występujący pomiędzy podstawami płyt spiral a ich czołami (rys. 3a),

b) przeciek osiowy - występujący dzięki występowaniu szczelin w punktach wspólnych (rys. 3b).

Celem przeprowadzonych obliczeń jest odpowiedź na pytanie, jaka jest natura przepływu przez szczelinę odpowiedzialną za przeciek wzdłużny.

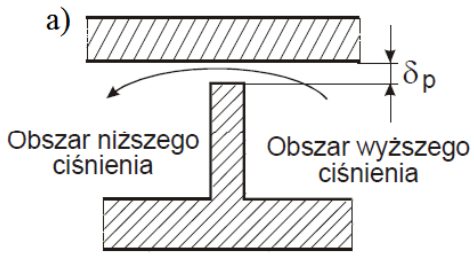

b)

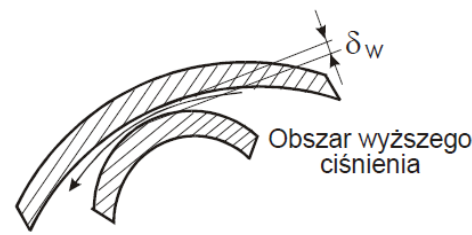

Rys. 3. Schemat występowania przecieków: a) przeciek promieniowy, b) przeciek osiowy

Fig. 3. Scheme of leakage occurrence: a) radial leakage, b) axial leakage

\section{Przecieki osiowe}

Strumień przepływu przez szczelinę zależy od pola przekroju nieszczelności, różnicy ciśnień pomiędzy komorami i współczynnika przepływu (równanie (1)). W literaturze przyjęło się stosować równania jak dla przepływu izentropowego (równanie (2)) [5, 6]:

$$
\begin{aligned}
& \dot{m}=\psi A_{s} f\left(p_{2}, p_{1}\right) \\
& \dot{m}=\psi A_{s} \sqrt{2 p_{1} \rho_{1}} \sqrt{\frac{k}{k-1}\left[\left(\frac{p_{2}}{p_{1}}\right)^{\frac{2}{k}}-\left(\frac{p_{2}}{p_{1}}\right)^{\frac{k+1}{2}}\right]}
\end{aligned}
$$

gdzie: $m$ - strumień masy, $\psi$ - współczynnik przepływu, $k$ - wykładnik adiabaty, $p_{1}$ - ciśnienie wyższe, $p_{2}$ - ciśnienie niższe, $\rho$ - gęstość.

Symulację przeprowadzono z zastosowaniem dwuwymiarowej, stacjonarnej siatki numerycznej, złożonej z 144255 elementów heksagonalnych. Geometria opiera się na kształcie rzeczywistej sprężarki. Obliczenia wykonano za pomocą metody objętości skończonych w pakiecie ANSYS CFX [7]. Założenia oraz warunki brzegowe zestawiono $\mathrm{w}$ tab. 1 . W obliczeniach przyjęto, że sprężarka 
jest bezolejowa, w związku z czym przepływ jest jednofazowy. Ze względu na bardzo niewielką szerokość kanału (rzędu mikrometrów) założono, że nawet przy dużych prędkościach liczba Reynoldsa nie przekroczy progu przepływu turbulentnego. Symulowany był stan nieustalony, w którym ciśnienie na wlocie rośnie liniowo w funkcji czasu, natomiast ciśnienie na wylocie pozostaje stałe. Wnikanie ciepła do ścian łopatek nie zostało uwzględnione, gdyż założono, że ze względu na szybkość procesu zjawisko to będzie miało drugorzędne znaczenie. Prędkość czynnika na ściankach to $0 \mathrm{~m} / \mathrm{s}$. Procedurę obliczeń zaplanowano w taki sposób, aby początkowo uzyskać wynik obliczeń w stanie ustalonym, dla ciśnienia $p_{1}=1,1 p_{2}$. Kryterium osiagnięcia stanu ustalonego było wyrównanie się wielkości strumieni masy na wlocie i wylocie z domeny. Wynik stanowił warunek początkowy do drugiej fazy obliczeń, przy zmiennym ciśnieniu wlotowym.

Tabela 1. Założenia i warunki brzegowe symulacji

Table 1. Assumptions and boundary conditions

\begin{tabular}{|l|c|}
\hline Czynnik & powietrze (gaz doskonały) \\
\hline Olej & brak \\
\hline Szerokość szczeliny & $20 \mu \mathrm{m}$ \\
\hline Rodzaj przepływu & laminarny \\
\hline Ciśnienie $\boldsymbol{p}_{\mathbf{2}}$ & $101300 \mathrm{hPa}$ \\
\hline Ciśnienie $\boldsymbol{p}_{\mathbf{1}}$ & od $1,1 p_{2}$ do $1,5 p_{2}$ \\
\hline Ściany & adiabatyczne \\
\hline
\end{tabular}

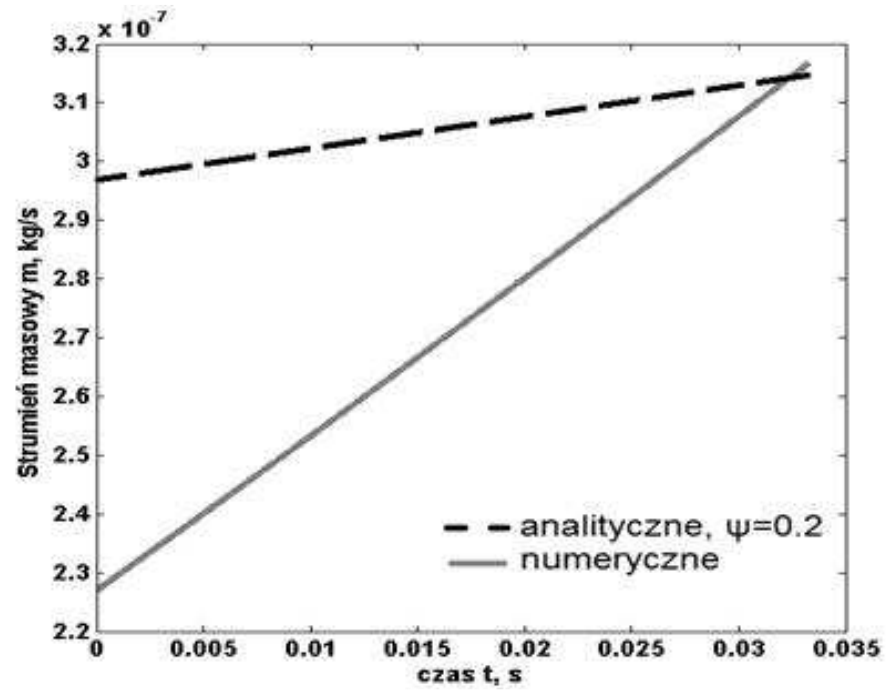

Rys. 4. Rozkład prędkości i ciśnienia przy $p_{1}=1,5 p_{2}$

Fig. 4. Velocity and pressure distribution for $p_{1}=1,5 p_{2}$ 
Wynikiem symulacji są pola ciśnień, prędkości i temperatury, a także strumień masy czynnika przepływającego przez szczelinę. Na rysunku 4. przedstawiono rozkład ciśnienia i prędkości na końcu symulacji. Maksymalna liczba Macha w tym przypadku była równa 0,36 . Jest to zatem przepływ podkrytyczny. Maksymalna prędkość rosła proporcjonalnie do wzrostu różnicy ciśnień. Druga obliczoną wielkością jest zmiana strumienia masy przepływającego przez nieszczelność. Na rysunku 5. pokazano, że natężenie przepływu rośnie liniowo z czasem, czyli także z ciśnieniem. Wynik uzyskany metodą numeryczną porównano z rozwiązaniem równania (2).

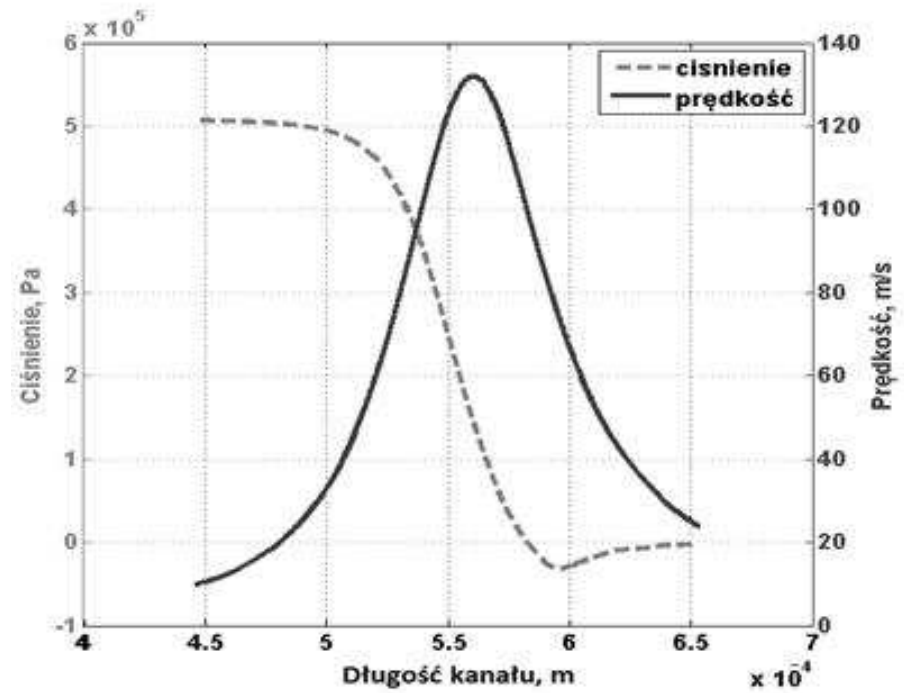

Rys. 5. Strumień masowy czynnika przepływającego przez nieszczelność

Fig. 5. Mass flow of the medium flowing through leakage

\section{Wnioski}

Dokonano modelowania numerycznego procesu przepływu przez szczelinę osiową sprężarki spiralnej. Wykazało ono liniową zależność strumienia masy od różnicy ciśnień pomiędzy komorami roboczymi, co jest zgodne z rozwiązaniem analitycznym na zadanym przedziale. Oba modele dają wyniki o zbliżonych wartościach, jednak z różnymi gradientami. Wykonana symulacja numeryczna pomaga zrozumieć zjawiska przecieków osiowych, będzie również wykorzystana do budowy dokładnych modeli całej maszyny spiralnej. Zjawisko to musi być uwzględnione w rozważaniach na temat parametrów działania sprężarki. 


\title{
Podziękowania
}

Obliczenia wykonano przy użyciu zasobów udostępnionych przez Wrocławskie Centrum Sieciowo-Superkomputerowe (http://wcss.pl), grant obliczeniowy nr 278.

\section{Literatura}

[1] Gnutek Z.: Łopatkowe maszyny rotacyjne. Oficyna Wydawnicza Politechniki Wrocławskiej, Wrocław 1997.

[2] Elson J.P., Kaemmer N., Wang S., Perevozchikov M.: Scroll Technology: An overview of past, present and future developments. Int. Compressor Engineering Conf., Purdue 2008.

[3] Quoilin S., Lemort V., Lebrun J.: Experimental study and modeling of an Organic Rankine Cycle using scroll expander. Appl. Energy, 87 (2012), 1260-1268.

[4] Mathias J., Johnston J., Cao J., Priedeman D., Christensen R.: Experimental testing of gerotor and scroll expanders used in, and energetic modeling of, an organic rankine cycle. J. Energy Resour. Technol., 131 (2009), 012201 (9 pages).

[5] Kang D.J., Kim J. W., Sohn C.B.: Effects of leakage flow model on the thermodynamic performance of a scroll compressor. Int. Compressor Engineering Conf., Purdue 2002.

[6] Pietrowicz S.: Modelowanie procesów termodynamicznych w maszynie spiralnej. Praca doktorska, Politechnika Wrocławska, Wrocław 2003.

[7] ANSYS Academic Research, Release 14.5, Help System, ANSYS Inc.

\section{TRANSIENT NUMERICAL ANALYSIS OF THE AXIAL LEAKAGE IN AN OIL-FREE SCROLL COMPRESSOR}

\begin{abstract}
S u m m a r y
In the paper the results of consideration of an axial leakage phenomena and its influence on the compression process in an oil-free scroll compressor were presented. With the use of a finite volume method a two-dimensional heat-flow phenomena model was proposed. It takes into account the boundary conditions in transient velocity, pressure and temperature in the chambers. Computational assumptions, results and conclusions about leakage influence on thermodynamical parameters of machine were presented.
\end{abstract}

Keywords: CFD, leakage, scroll compressor, modeling, rotary machines

DOI: $10.7862 / \mathrm{rm} .2014 .61$

Otrzymano/received: 20.07.2014 r.

Zaakceptowano/accepted: 22.11.2014 r. 